\title{
Prevalence of Kidney impairment and its associated factors among HIV-infected antiretroviral treatment-naïve adult patients in Bayelsa State, Nigeria
} Egbi OG

\author{
Department of Internal Medicine, Niger Delta University, Amassoma, Bayelsa State, Nigeria
}

Submitted: $21^{\text {st }}$ May 2021

Accepted: $15^{\text {th }}$ June 2021

Published: $30^{\text {th }}$ June 2021

\begin{abstract}
Objective: The study aimed to determine the prevalence of kidney impairment $(\mathrm{KI})$ and associated factors among HIV antiretroviral treatment (ART) - naïve patients in Bayelsa State in the Niger Delta area of Nigeria.

Methodology: A retrospective study was carried out in the Niger Delta University Teaching Hospital (NDUTH) using case notes of patients who presented from 2011 - 2020. Socio-demographic, clinical, and laboratory data were retrieved. The Chronic Kidney Disease (CKD) Epidemiology (EPI) Collaboration formula and Cockcroft Gault equation were used in estimating the glomerular filtration rate (eGFR) and creatinine clearance $(\mathrm{CrCl})$ respectively. $\mathrm{KI}$ was defined as eGFR $<60 \mathrm{mls} / \mathrm{min}$.

Results: The prevalence of $\mathrm{KI}$ was $13.8 \%$. Up to $59.5 \%$ had $\mathrm{CrCl}$ below $90 \mathrm{mls} / \mathrm{min}$. KI showed significant association with age $>45$ years, married status, presence of co-morbidity, and high HIV RNA load. However, only age was independently associated with $\mathrm{KI}\{$ AOR $3.4\{\mathrm{CI} 1.2-9.6 \mathrm{p}=0.018)\}$.

Conclusion: The prevalence of $\mathrm{KI}$ was $13.8 \%$ while up to $50.5 \%$ had reduced $\mathrm{CrCl}$. Age $<45$ years was the only determinant of KI though 'being married', having co-morbidities and high viral load also showed significant association. There is a need for regular assessment of renal function in HIV- infected patients.
\end{abstract}

Keywords: antiretroviral treatment, human immunodeficiency virus, estimated glomerular filtration rate, kidney impairment, prevalence

\section{Plain English Summary}

The study was carried out as a retrospective review of all HIV- infected cases who attended the HIV clinic of the Niger Delta University Teaching Hospital, Bayelsa State, Nigeria from 2011 to 2020 before initiation of antiretroviral treatment. The aim was to determine the prevalence of kidney impairment (reduced kidney function) and its associated factors. Kidney impairment was quite common among the patients. Individuals who were older, married, with high viral load, and who had other associated medical conditions were at higher risk of kidney impairment though age was found to be the sole independent predictor.

\section{Background}

Human immunodeficiency virus (HIV) infection has continued to pose a major health challenge particularly in Sub-Saharan Africa (SSA) where it has been reported to have the highest incidence in the world with almost two-thirds of the global total of new infections and mortality of up to $65 \%$ $(1,2,3)$.

Nigeria was reported to have the second-largest HIV epidemic in the world, next only to South

Correspondence:

Egbi, Oghenekaro G

Department of Internal Medicine

Niger Delta University, Amassoma, Bayelsa State, Nigeria

+2348036583634 drkoge@yahoo.com

(c) BUMJ. 2020 Open Access This article is distributed under the terms of the Creative Commons Attribution 4.0 International License

(http://creativecommons.org/licenses/by/4.0/), which permits unrestricted use, distribution, and reproduction in any medium, provided you give appropriate credit to the original author(s) and the source, provide a link to the Creative Commons license, and indicate if changes were made. The Creative Commons Public Domain Dedication waiver

(http://creativecommons.org/publicdomain/zero/1.0/) applies to the data made available in this article, unless otherwise stated 
Africa, with 1.9 million persons living with the virus and 53,000 acquired immune deficiency syndrome (AIDS) - related deaths, partly contributed to by its large population $(4,5)$ Although with a declining prevalence now put at about $1.4 \%$, up to two-thirds of new HIV infections in West and Central Africa still occur in Nigeria (4, 5).

The complications of HIVIAIDS may be varied, affecting several organs and systems at various stages, including the kidneys, especially if left untreated. Renal involvement in HIV may be due to direct infection of the kidneys by the virus, immunologic reactions, opportunistic infections as well as adverse effects of antiretroviral therapy (ART) (6). The clinical presentation may include HIV- associated nephropathy (HIVAN), HIVimmune complex-mediated glomerulonephritis, thrombotic microangiopathy (7).

The estimated prevalence of renal disease in HIV infected patients in SSA ranges from $6 \%$ to 46.5 $\%(8,9,10)$. Not only does the prevalence of HIV vary across geographical zones worldwide, but its distribution may also vary even within regions or states in a country or territory. For instance, in Nigeria, there are variations in the prevalence of HIV across different states (11). This may also apply to the distribution of renal disease and may be attributable to differences in modifying factors such as demographics, socio-economic factors, as well as environmental factors. Although there have been alarming reports of prevalence rates of renal disease in the HIV population of up to $50 \%$ in both southern and northern Nigeria $(12$, 13 ), it appears that the prevalence of kidney impairment $(\mathrm{KI})$ is still unknown in many centers offering care to people living with HIVI AIDS (PLWHA). Determining the baseline renal function before ART initiation is important as it has been identified as a predictor of death in these individuals (14). There is a paucity of such data among HIV patients in Bayelsa state, a prominent oil hub in the Niger Delta region of Nigeria. The state had been ranked among those with the highest prevalence of HIV about a decade ago (15) though the rates of new infection seemed to have dropped over the years.

The objective of the study was therefore to determine the prevalence and associated factors of $\mathrm{KI}$ among ART naïve patients in Bayelsa state, Nigeria.

\section{Methods}

\section{Study setting}

This study was conducted in the anti-retroviral clinic (ARC) of the Niger Delta University Teaching Hospital (NDUTH). This tertiary hospital is located at Okolobiri, a semi-rural community in Bayelsa State in south-south Nigeria. Bayelsa state is one of the core states constituting the Niger Delta region of Nigeria. This region is widely known in Africa for oil production and exploration but there are also attendant issues such as oil pollution, gas flaring, and environmental degradation which may negatively impact the health of the residents.

The hospital serves as a referral center for the management of HIVIAIDS for health facilities within the state and neighboring states such as Delta, Rivers, Imo, Edo, etc. The ARC in the hospital holds twice every week and provides screening, investigative and therapeutic services for HIV-infected patients. The staff of the clinic includes consultants in infectious disease, residents in internal medicine, nurses, record clerks, and other support staff.

\section{Study Design}

The study was retrospective in design. It was both descriptive and analytical. Data of all HIV-infected ART naïve patients who received clinical care in NDUTH were retrieved from their case notes accessed via the medical records department.

\section{Study population}

The study population comprised of HIV seropositive adults who presented to the ARC of the hospital. Inclusion criteria for the study were age $>18$ years old, individuals of Nigerian nationality, and confirmed HIV seropositivity.

Exclusion criteria included elderly $>65$ years old, pregnant women, individuals with other established causes of renal disease, and those with missing data on serum creatinine and estimated glomerular filtration rate (eGFR). Also excluded were individuals who were already on ART before the initial review or who had a recent history of use of nephrotoxic medications or drugs likely to affect serum creatinine concentration.

\section{Sampling and sample size determination}

The sample size for the study was determined from the formula:

$N=Z^{2} P(1-P) / d^{2}$ where $N=$ minimum sample size, $Z=$ normal standard deviation at $95 \%$ confidence interval $=1.96, P=$ proportion of the population with the desired characteristic. $d=$ degree of precision $=5 \%$. Using the Chronic Kidney Disease Epidemiology Collaboration (CKD EPI) formula in the estimation of CKD, (as 
was also used in this study), Erikpo et al reported a prevalence of $13.4 \%$ in Uyo, Nigeria (16). Applying a $\mathrm{P}$ of $13.4 \%(0.134)$ in the formula gives an ' $N$ ' of 178 . As a step towards ensuring that the study was well powered, the sample size was increased to 210 . Going backward from the year 2020, case notes of new patients seen in the clinic were examined, and those that met the criteria for inclusion were selected for the study until the sample size was achieved

\section{Study procedure}

Data were obtained from the patients' case records and included socio-demographics such as age, gender, marital status, history of smoking and alcohol consumption, anthropometrics such as weight and body mass index (BMI). Clinical data such as HIV clinical staging, systolic blood pressure (SBP), and diastolic blood pressure (DBP) at the initial visit as well as a history of comorbid illness and other relevant aspects of the past medical history were also captured. The 2006 WHO classification was used in the clinical staging of HIVIAIDS (17). Laboratory parameters retrieved included hematocrit level, serum creatinine, and CD4 T lymphocyte count. The case notes were also checked for the initial viral load done 6 months after initiating ART (for those with available results), at which time viral suppression is expected.

Data were extracted into a questionnaire containing sections for the various parameters. The eGFR was calculated with the CKD EPI formula. The CKD-EPI was used in this study because it has shown high accuracy in HIV patients when compared with direct estimates of glomerular filtration rate (18). The eGFR was graded into five stages, according to the National Kidney Foundation grading of CKD (19). Creatinine clearance $(\mathrm{Cr}-\mathrm{Cl})$ was also estimated with the Cockcroft- Gault equation (20).

\section{Definition of Terms}

For the study, the following terms were used as defined. Marital status was categorized into two classes: the 'never married' group (individuals that were single and have never been married) and the 'ever married; group (individuals that have been married). The latter was further categorized into two groups: 'married and living together (individuals who were living together with their spouses) and 'married but living apart' (including the separated, divorced, and widowed group).

Co-morbidity was defined as the presence of medical conditions co-existing with the HIV infection but independent of it such as diabetes, hypertension, and heart disease.

The BMI was classified into the following categories: underweight (BMl $\left.<18.5 \mathrm{~kg} / \mathrm{m}^{2}\right)$, normal weight $(18.5-24.9 \mathrm{~kg} / \mathrm{m} 2$ and the 'overweight / obese group (BMI $\geq 25 \mathrm{~kg} / \mathrm{m}^{2}$ ). These values are in keeping with existing criteria (21).

HIVI AIDS was clinically staged into four categories depending on the initial clinical presentation of the patients (17). For ease of analysis, the first two stages were considered as 'early' while the last two stages were considered as 'advanced.'

Elevated SBP was defined as a recorded SBP > $140 \mathrm{mmHg}$ on at least two separate occasions. Similarly, elevated DBP was defined as a recorded DBP $>90 \mathrm{mmHg}$ on at least two separate occasions (22).

A viral load of more than 1000 copies $/ \mathrm{ml}$ were taken to be virally non-suppressed while lesser values were considered 'suppressed' (23).

Kidney impairment was defined as eGFR< $60 \mathrm{mls} / \mathrm{min}$ while reduced creatinine clearance was defined as $\mathrm{Cr}-\mathrm{Cl}<90 \mathrm{mls} / \mathrm{min}$ (19).

\section{Data Analysis}

Data were stored and analyzed using the Statistical Product and Service Solution (SPSS 20.0). The prevalence of KI was determined by a simple proportion of those with $\mathrm{KI}$ compared with the total population studied. The student t-test was used for comparison of continuous data while chi-square and fisher's exact tests were used to compare discrete data. Univariate logistic regression was used in testing the association of independent variables with the dependent variable while multivariate logistic regression was used to identify the significance of the predictor variables. $\mathrm{KI}$ was taken as the dependent variable while the independent variables tested included demographics (such as age, sex, and marital status), clinical variables (body mass index, clinical staging), elevated SBP, elevated DBP) and laboratory parameters (such as CD4 T lymphocyte count). The multivariate analysis used the method of forward-selection of variables. The odds ratio was computed and confidence intervals were generated with the $95 \%$ confidence limits. All tests were two-tailed with $p<0.05$ considered as statistically significant. Results were presented in form of tables and charts.

\section{Results}


A total of two hundred and ten cases were used for analysis after excluding those with incomplete data and those who did not satisfy the inclusion criteria.

The mean age of the patients was $40.07 \pm 9.63$ years and ranged from $19-65$ years. The females outnumbered the males accounting for $124(59.0 \%)$ cases. Most of the participants (139; $66.2 \%$ ) were married. Twelve $(5.7 \%)$ were either separated, divorced, or widowed. The sociodemographic data, as well as the clinical and laboratory parameters of the patients, are shown in table 1. Clinical stages I and III accounted for the highest proportion of cases $(31.4 \%$ and
$31.0 \%$ respectively) while stage IV had the least proportion (12.4\%). Twenty-six (12.4\%) of them had a co-morbid condition present. Pulmonary tuberculosis (3.3\%) and hypertension (2.9\%) were the commonest comorbidities in the patients. Skin infections $(1.4 \%)$, heart disease $(0.95 \%)$, and toxoplasmosis infection $(0.95 \%)$ were also seen. The mean BMl was normal in $110(52.4 \%)$ patients with a mean of $22.35+4.61$ $\mathrm{kg} / \mathrm{m}^{2}$ While $39(18.6 \%)$ individuals were underweight, forty-six $(21.9 \%)$ were overweight or obese. Ten (4.8\%) patients had elevated SBP while $13(6.2 \%)$ had elevated DBP.

Table 1: Socio-demographic, clinical, and laboratory variables of patients

\begin{tabular}{|c|c|c|}
\hline $\begin{array}{c}\text { Variable } \\
\end{array}$ & Mean \pm SD & Frequency $\mathrm{n}(\%)$ \\
\hline \multicolumn{3}{|l|}{ Socio-demographic variables } \\
\hline Age(years) & $40.07+9.63$ & \\
\hline $\operatorname{Sex}(n=210)$ & - & \\
\hline Male & & $86(41.0)$ \\
\hline Female & & $124(59.0)$ \\
\hline Marital status $(n=210)$ & - & \\
\hline Never married & & $59(28.1)$ \\
\hline Married and living together & & $139(66.2)$ \\
\hline Ever married but living apart & & $12(5.7)$ \\
\hline \multicolumn{3}{|l|}{ Alcohol $(n=158)$} \\
\hline Yes & - & $8(5.1)$ \\
\hline No & & $150(94.9)$ \\
\hline Smoking $(n=142)$ & - & \\
\hline Yes & & $1(0.7)$ \\
\hline No & & $141(99.3)$ \\
\hline \multicolumn{3}{|l|}{ Clinical and Laboratory variables } \\
\hline Clinical stage of HIV & & - \\
\hline 1 & $66(31.4)$ & \\
\hline II & $53(25.2)$ & \\
\hline III & $65(31.0)$ & \\
\hline IV & $26(12.4)$ & \\
\hline \multicolumn{3}{|l|}{ CD4 count cells/ $/ \mathrm{l}(\mathrm{n}=210)$} \\
\hline$<200$ & & 83(39.5) \\
\hline 200- 499 & & $102(48.6)$ \\
\hline$\geq 500$ & & $25(11.9)$ \\
\hline \multicolumn{3}{|l|}{ Viral load $(n=79)$} \\
\hline Suppressed & & $56(70.9)$ \\
\hline Not suppressed & & $23(29.1)$ \\
\hline \multicolumn{3}{|l|}{ Presence of comorbidity } \\
\hline Yes & $26(12.4)$ & \\
\hline No & 184(87.6) & \\
\hline Weight (kg) & $59.9+13.4$ & - \\
\hline BMI $\left(\mathrm{kg} / \mathrm{m}^{2}\right)$ & $22.35+4.61$ & - \\
\hline $\mathrm{SBP}(\mathrm{mmHg})$ & $118.59 \pm 17.03$ & - \\
\hline $\mathrm{DBP}(\mathrm{mmHg})$ & $75.96+12.09$ & - \\
\hline Hematocrit & $30.7 \overline{3}+5.56$ & - \\
\hline CD4 count (cells/ul) & $265.76 \pm 209.34$ & -- \\
\hline
\end{tabular}


Only 26 participants had CD4 count $>500$ cells $/ \mu$ l. HIV viral load result was only available in $79(37.6 \%)$ cases. Out of this proportion, viral suppression was documented in $56(70.9 \%)$ while in $23(29.1 \%)$, it was not suppressed.

Similarly, only 128 (60.9\%) had available hematocrit reports with a mean of $30.73 \pm 5.56$. Also, urinalysis was only available in $31(1 \overline{4} .8 \%)$ individuals. Out of this, $12(38.7 \%)$ had at least $1+$ proteinuria while $5(16.1 \%)$ had glycosuria.
The mean eGFR of the patients was $86.89 \pm 28.32$ $\mathrm{mls} / \mathrm{min}$ and is classified in table 2. The prevalence of $\mathrm{KI}$ was $13.8 \%$ (found in 29 patients). Twenty-one $(10.0 \%)$ were in stage 3 CKD, while $4(1.9 \%)$ each were in stage 4 and stage 5 CKD (Figure 1). On the other hand, up to $125(59.5 \%)$ individuals had reduced creatinine clearance $(<90 \mathrm{mls} / \mathrm{min})$ while forty-two $(20.0 \%)$ had $\mathrm{Cr} C l<60 \mathrm{mls} / \mathrm{min}$.

Table 2: Comparison of characteristics of HIV Patients with and without kidney impairment

\begin{tabular}{|c|c|c|c|}
\hline Characteristics & $\begin{array}{c}\text { Patients with KI } \\
\text { n (\%) }\end{array}$ & $\begin{array}{c}\text { Patients without KI } \\
\text { n (\%) }\end{array}$ & $\boldsymbol{P}$ \\
\hline \multicolumn{4}{|l|}{ Age } \\
\hline$<45$ & 21(20.4) & $82(79.6)$ & $0.009^{*}$ \\
\hline$>45$ & $8(7.5)$ & $99(92.5)$ & \\
\hline \multicolumn{4}{|l|}{ Sex } \\
\hline Male & 15(17.4) & $71(82.6)$ & 0.226 \\
\hline Female & 14(11.3) & $110(88.7)$ & \\
\hline \multicolumn{4}{|l|}{ Marital status } \\
\hline Married but not living with a spouse & $5(41.7)$ & $7(58.3)$ & \\
\hline Married and living with a spouse & 22(15.8) & $117(84.2)$ & $0.001^{*}$ \\
\hline Never married & $2(3.4)$ & $57(96.6)$ & \\
\hline \multicolumn{4}{|l|}{$\mathrm{BMI}\left(\mathrm{kg} / \mathrm{m}^{2}\right)$} \\
\hline$\geq 25$ & $5(10.9)$ & 41(89.1) & \\
\hline$<18.5$ & $9(23.1)$ & $30(76.9)$ & 0.214 \\
\hline $18.5-24.9$ & 15(12.0) & $110(88.0)$ & \\
\hline \multicolumn{4}{|l|}{ Clinical staging } \\
\hline Advanced & 15(16.7) & $75(83.3)$ & \\
\hline Early & 14(11.7) & $106(88.3)$ & 0.318 \\
\hline \multicolumn{4}{|l|}{ CD4 count } \\
\hline$<200$ & 14(16.9) & $69(83.1)$ & \\
\hline $200-500$ & $13(12.9)$ & $88(87.1)$ & 0.538 \\
\hline$>500$ & $2(8.0)$ & $23(92.0)$ & \\
\hline \multicolumn{4}{|l|}{ Viral load (79) } \\
\hline Not suppressed & $6(4.4)$ & $47(45.4)$ & \\
\hline Suppressed & $9(10.6)$ & $17(16.6)$ & $0.03^{*}$ \\
\hline \multicolumn{4}{|l|}{ Presence of co-morbidity } \\
\hline Yes & $8(30.8)$ & 18(69.2) & \\
\hline No & $21(11.4)$ & $163(88.6)$ & $0.014^{*}$ \\
\hline \multicolumn{4}{|l|}{ SBP } \\
\hline Elevated & $3(10.3)$ & 26(89.7) & \\
\hline Normal & $7(3.9)$ & 174(96.1) & 0.145 \\
\hline \multicolumn{4}{|l|}{ DBP } \\
\hline Elevated & $4(13.8)$ & $25(86.2)$ & \\
\hline Normal & $9(5.0)$ & $172(95.0)$ & 0.086 \\
\hline
\end{tabular}


Figure 1: Frequency of the various stages of the eGFR among the patients

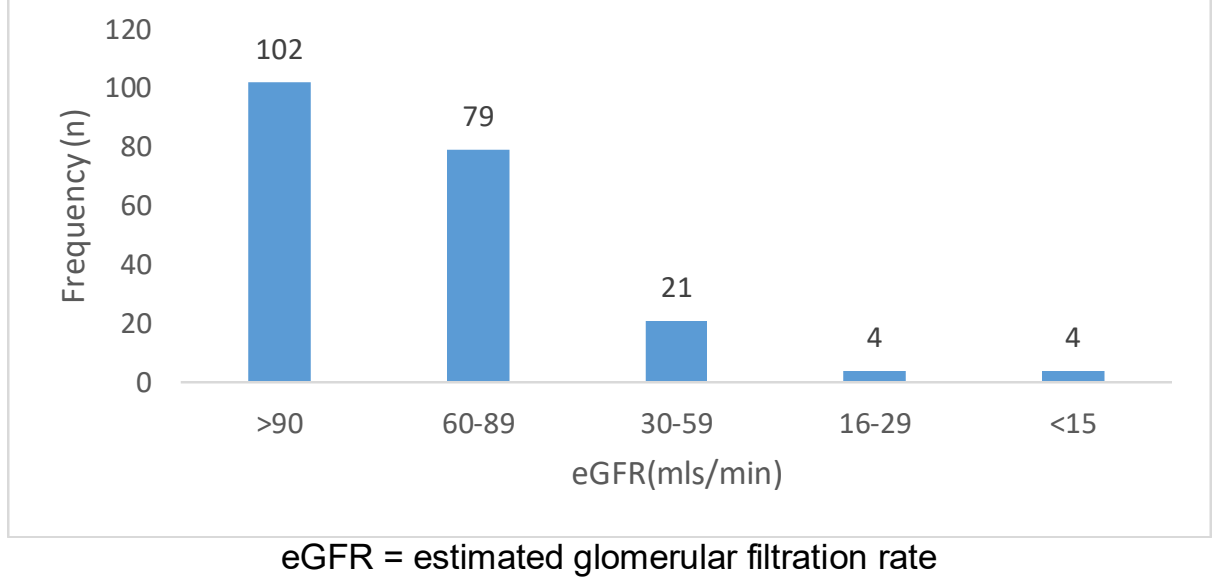

The characteristics of HIV patients with $\mathrm{KI}$ are compared with those without $\mathrm{KI}$ in table 3 . HIV patients with $\mathrm{KI}$ were more likely to be older $(p=0.009)$, married $(p=0.001)$, have at least a comorbidity $(p=0.01)$ with higher viral loads $(p=$ 0.03 ) compared with those without renal diseases (table 3). There was no significant difference in the other parameters compared $(p>0.05)$.

Table 3: Logistic regression of factors associated with kidney impairment among the patients

\begin{tabular}{|c|c|c|c|c|}
\hline \multirow[b]{2}{*}{ Factors } & \multicolumn{2}{|c|}{ Univariate } & \multicolumn{2}{|c|}{ Multivariate } \\
\hline & $\mathrm{OR}(\mathrm{Cl})$ & $P$ & $\mathrm{OR}(\mathrm{Cl})$ & $P$ \\
\hline Age $>45$ years & $4.994(2.203-11.317$ & $<0.001^{*}$ & $3.432(1.231-9.569)$ & $0.018^{*}$ \\
\hline$<45$ years & 1 & & & \\
\hline Sex female & $0.602(0.274-1.324)$ & 0.207 & $0.810(0.303-2.168)$ & 0.675 \\
\hline Male & 1 & & & \\
\hline \multicolumn{5}{|l|}{ Marital status } \\
\hline Married but living apart & $20.357(3.305-125.393)$ & & $5.5699(0.639-50.861)$ & 0.280 \\
\hline Married and living together & $5.359(1.318-23.583)$ & $0.005^{*}$ & & \\
\hline Single & 1 & & & \\
\hline \multicolumn{5}{|l|}{$\operatorname{BMI}\left(\mathbf{k g} / \mathrm{m}^{2}\right)$} \\
\hline$>25$ & $0.894(0.306-2.617$ & 0.187 & $0.825(0.249-2.728$ & 0.587 \\
\hline$<18.5$ & $2.200(0.877-5.519)$ & & & \\
\hline $18.5-24.9$ & 1 & & & \\
\hline \multicolumn{5}{|l|}{ Clinical staging } \\
\hline Advanced disease & $1.514(0.690-3.324)$ & 0.301 & $0.778(0.272-2.231)$ & 0.641 \\
\hline Early disease & 1 & & & \\
\hline \multicolumn{5}{|l|}{ CD4 count } \\
\hline$<200$ & $2.333(0.483-11.048)$ & 0.492 & $2.113(0.341-13.098)$ & 0.719 \\
\hline $200=500$ & $1.680(0.354-7.975)$ & & $1.915(0.335-10.961)$ & \\
\hline$>500$ & 1 & & & \\
\hline \multicolumn{5}{|l|}{ Presence of co-morbidity } \\
\hline Yes & $3.450(1.336-8.909)$ & $0.011^{*}$ & $2.958(0.916-9.549)$ & \\
\hline No & 1 & & & 0.07 \\
\hline \multicolumn{5}{|l|}{ SBP } \\
\hline Elevated & $2.868(0.698-11.794$ & 0.144 & $2.347(0.253-21.788)$ & 0.453 \\
\hline Normal & 1 & & 1 & \\
\hline \multicolumn{5}{|l|}{ DBP } \\
\hline $\begin{array}{l}\text { Elevated } \\
\text { Normal }\end{array}$ & $3.058(0.676-10.676)$ & 0.080 & $0.449(0.049-4.083)$ & 0.477 \\
\hline BMI = body mass & & & & \\
\hline
\end{tabular}


Univariate logistic regression showed an association of $\mathrm{KI}$ with age $>45$ years $\{4.9$ (2.2$11.3)\}$, presence of co-morbidity $3.450(1.318$ $23.583)$ and married status $\{(20.357(3.305-$ 125.393) for married but living apart\} and \{5.4(1.3-23.6)\} for married and living together\}. However, on multivariate analysis, only age $>45$ years independently predicted $\mathrm{KI}$ in the HIV patients [AOR 3.4 (1.2-9.6)]. The other variables were not found to be significant in the model.

\section{Discussion}

The prevalence of kidney impairment among the HIV patients in this study was $13.8 \%$ with almost $60 \%$ of them having a reduced creatinine clearance. This is comparable to the $13.4 \%$ reported by Erikpo et al who used a similar method to estimate kidney function (16). Direct comparison of findings across available studies is however constrained due to differing methodologies and study designs employed. Umeizudike et al found a prevalence of $23.5 \%$ in their cross-sectional case-control study in Lagos, South-West Nigeria (24), while Emem-Chioma reported an even higher rate of $38 \%$ in Port Harcourt., South-South, Nigeria (9). In both studies, CKD was defined as the presence of albuminuria and/or reduced kidney function unlike in our study where we used only the latter. Only a few of our patients had a record of urinalysis while quantitative estimation of albumin, albumin/creatinine, or protein/creatinine ratio was not available. The difference in prevalence reported by Emem-Chioma could have partly resulted from the use of absolute creatinine value (serum creatinine $>132 \mu \mathrm{mol} / \mathrm{l}$ ) to define CKD, rather than an estimating formula. Also, the study was done over a decade ago. The use of GFR has replaced serum creatinine in the estimation of renal function.

Reports from studies in Jos, North Central Nigeria reveal higher prevalence rates of $23.8 \%,(24)$ $30.8 \%$ (25), and $51 \%(13)$ for different studies. Dada et al found similarly found a higher prevalence of $47.6 \%$ in Ilorin (26). While Anyabolu found a prevalence of $22.9 \%$ in a study that excluded the elderly (27), they were part of the study population in Dada's study. Anyabolu used a $24 \mathrm{~h}$ hour urine protein $>0.3 \mathrm{~g} / 24 \mathrm{hrs}$, and eGFR < 60nls/min as indicative of CKD, (27) while Dada used spot urine albumin/ creatinine ratio in place of 24-hour analysis. It is not surprising that we found a lower prevalence rate than most of these studies as we restricted our definition of $\mathrm{KI}$ to a reduction in kidney function.
Studies done in North America and Europe have revealed lower prevalence rates of HIVassociated kidney disease of $2.5 \%$ to $7.4 \%$ (16, $28,29)$ when CKD is defined as eGFR < $60 \mathrm{mls} / \mathrm{min} / 1.73 \mathrm{~m}^{2}$ similar to the criteria we used. However, the study by Mocroft et al was a prospective, large-scale, multicenter study done among a relatively older population compared with ours which was a small-scale, single-center, retrospective study (28). Some studies in Africa and Asia have similarly reported low prevalence rates $\{(5.5-6 \%$ for South Africa (8) and $7.0 \%$ for Taiwan (30). This may be due to differences in genetic predisposition and/or geographic or environmental susceptibilities. The mean age of the population in most of these studies was not much different from that of ours. Once again, CKD prevalence is largely dependent on the criteria used for the diagnosis of CKD or renal impairment. For instance, when proteinuria was added in the definition of CKD, the prevalence of CKD in the USA increased to $15.5 \%(28,31,32)$. Demographic factors that have been reported to be associated with renal disease in HIV patients from previous reports include age $(9,24,33)$, gender (9), and marital status (33). The patients in Emem-Chioma's study were between 18 and 65 years (9), similar to our population while in Huda's study, the range was from 15-65 years among disadvantaged communities in Bangladesh (33). On the other hand, Umeizudike et al recruited adults who were at least 18 years old (24). HIV patients older than 45 years had increased odds for the development of renal disease in our study. This is consistent with the findings of the study by Huda et al where the middle-aged and elderly population were reported to have a greater tendency to develop CKD compared with the young and early middleaged (33). However, no association with age was found in Abene's study (26) Individuals who were married had an increased risk for renal diseases, especially for those who were married but no longer living together, though this variable failed to remain significant on multivariate analysis. Huda similarly also reported an association of married status with renal diseases, though a regression analysis was not done in the study (33).

There was no gender predilection for CKD among our patients. This is similar to the report of Anyabolu et al (27) but different from that of Abene et al that showed a male predilection (26) and Agbaji et al that showed an association with the female gender (25). The reason for these 
discrepancies is not clear and may warrant further studies.

We did not find any significant association between CKD and CD4 T lymphocyte count in this study. Similarly, Agaba et al reported no differences in CD4 cell counts between HIVIAIDS patients with and without kidney disease (13). Renal disease in HIV/ AIDS is multifactorial in etiology and could therefore occur at any stage of the disease. Contrary to our findings, however, some studies have found a negative correlation between renal dysfunction in HIV and CD4 cell count $(9,24,25,30,34,35)$. Another parameter that is usually indicative of disease severity in these patients is the HIV RNA viral load. In our study, the group with $\mathrm{KI}$ as compared with that without KI had a higher proportion of Individuals with a lack of suppression of viral load. However, only a few patients had documented evidence of viral load results. Therefore, it was not entered as an independent variable into the logistic regression model. Studies have shown that the viral load is a better predictor and determinant of adverse events than the CD4 count $(36,37)$. In Abene's study, viral load was shown to be an independent predictor of CKD (26).

The presence of co-morbidities in our population was also found to be associated with CKD but only on univariate analysis. Studies have shown increased odds for CKD among HIV patients with co-morbidities such as hypertension and diabetes $(30,38)$. The association of these comorbid medical conditions with the risk of development of CKD in HIV patients is not clear and may need further investigations. Some studies have also reported a negative association of CKD with BMI in HIV patients $(9,26,27)$. However, we found no such association with BMI in this study in keeping with some previous reports in Nigeria $(35,39)$.

The study had some limitations. Serum creatinine was done only once. Urinalysis was only reported for a few patients. Kidney impairment was defined based on only reduced eGFR implying that those with isolated albuminuria, hematuria, or structural renal abnormalities must have been excluded leading to an underestimation of KI. The study design was retrospective and relied on already collected data, leading to incidences of missing and incomplete information.

\section{Conclusion}

We report a fairly high prevalence rate of $\mathrm{KI}$ and reduced creatinine clearance in our ART-naive patients which is quite comparable to previous reports. Factors associated with $\mathrm{KI}$ in this study were age, marital status, presence of comorbidities, and viral load. However, only age >45 years remained as an independent predictor on multivariate analysis. These findings are important as commonly used drugs may require some dose adjustment in these patients. This also has implications for use of potentially nephrotoxic medications such as tenofovir which is still commonly used as part of first-line ART in our settings. There is a need for assessment of baseline renal functions and regular monitoring of kidney function in HIV-infected patients.

$\begin{array}{ll}\text { List of Abbreviations } \\ \text { AIDS: } & \text { Acquired immunodeficiency } \\ & \text { syndrome } \\ \text { AOR: } & \text { Adjusted odds ratio } \\ \text { ARC: } & \text { Antiretroviral clinic } \\ \text { ART: } & \text { Antiretroviral treatment } \\ \text { BMI: } & \text { Body mass index } \\ \text { CD: } & \text { Cluster of differentiation } \\ \text { CKD: } & \text { Chronic kidney disease } \\ \text { Cr-Cl: } & \text { Creatinine clearance } \\ \text { DBP: } & \text { Diastolic blood pressure } \\ \text { HIV: } & \text { Human immunodeficiency virus } \\ \text { HIVAN: } & \text { Human immunodeficiency virus- } \\ & \text { associated nephropathy } \\ \text { KI: } & \text { Kidney impairment } \\ \text { NDUTH: } & \text { Niger Delta University Teaching } \\ & \text { Hospital } \\ \text { OR: } & \text { Odds ratio } \\ \text { PLWH: } & \text { People living with HIVIAIDS } \\ \text { RNA: } & \text { Ribonucleic acid } \\ \text { SBP: } & \text { Systolic blood pressure }\end{array}$

\section{Declarations}

\section{Ethics consideration}

Ethical approval for the study was obtained from the Research Ethics Committee of the Niger Delta University Teaching Hospital (NDUTH). Ethical principles of anonymity and confidentiality of obtained information were upheld.

\section{Consent for publication}

The author hereby gives consent for the publication of this work under the creative Commons CC Attribution. Non-commercial 4.0 license.

\section{Availability of data and materials}

Data and other materials associated with this research will be made available by the corresponding author upon reasonable request.

Conflict of interest 
The author declares that he has no competing interests

\section{Funding}

This research did not receive any specific grant from funding agencies in the public, commercial, or not-for-profit sectors

\section{Authors; contribution}

The study was solely authored by OGE.

\section{Acknowledgments}

The author wishes to acknowledge Drs Hendris J. Izibewule and Braide-Buseni C. Sotom, of the infectious disease unit as well as the house officers of the department of medicine of the Niger Delta University Teaching Hospital for assisting in the data collection. Our appreciation also goes to the staff of the Medical Records Department for their assistance and co-operation in the retrieval of the relevant hospital case notes

\section{References}

1. James SL, Abate $\mathrm{D}$, Abate $\mathrm{KH}$, Abay SM, Abbafati $\mathrm{C}$, Abbasi $\mathrm{N}$, Abbastabar $\mathrm{H}$, AbdAllah F, Abdela J, Abdelalim A, Abdollahpour I. Global, regional, and national incidence, prevalence, and years lived with disability for 354 diseases and injuries for 195 countries and territories, 1990-2017: a systematic analysis for the Global Burden of Disease Study 2017. The Lancet. 2018 Nov 10;392(10159):1789-858.

https://doi.org/10.3410/f.731220250.7935698 75

2. $\overline{\mathrm{WHO}}$ fact sheet HIVIAIDS. Key facts. https://doi.org/10.1037/e503022010-001

3. Roth GA, Abate D, Abate KH, Abay SM, Abbafati C, Abbasi $\mathrm{N}$, Abbastabar $\mathrm{H}$, AbdAllah F, Abdela J, Abdelalim A, Abdollahpour I. Global, regional, and national age-sexspecific mortality for 282 causes of death in 195 countries and territories, 1980-2017: a systematic analysis for the Global Burden of Disease Study 2017. The Lancet. 2018 Nov 10;392(10159):1736-88.

https://doi.org/10.1016/s01406736(14)61682-2

4. UNAIDS. Country factsheet Nigeria. HIV and AIDS estimate 2019. Available at https://www.unaids.org/en/regionscountries/c ountries/nigeria. Accessed_June 6. 2021.

5. Avert Global information and education on HIV and AIDS. HIV and AIDS in Nigeria. Available https://www.avert.org/professionals/hivaround-world/sub-saharan-africa/nigeria. Accessed May 7, 2021.

6. Bruggeman LA, Bark C, Kalayjian RC. HIV and the kidney. Current infectious disease reports. 2009 Nov 1;11(6):479. https://doi.org/10.1007/s11908-009-0069-4

7. Swanepoel CR, Atta MG , D'Agati VD , Estrella MM, Fogo AB, Naicker S, Post FA Wearne N, Winkler CA, Cheung M, Wheeler DC, Winkelmayer WC, Wyatt CM. Conference Participants. Kidney disease in the setting of HIV infection: conclusions from a Kidney Disease: Improving Global Outcomes (KDIGO) Controversies Conference Kidney Int 2018; 93, 545-559. https://doi.org/10.24884/1561-6274-2018-226-84-100

8. Han TM, Naicker S, Ramdial PK, Assounga AG. A cross-sectional study of HIVseropositive patients with varying degrees of proteinuria in South Africa. Kidney Int. 2006, $69 \quad(12)$ : 2243-50. https://doi.org/10.1038/sj.ki.5000339

9. Emem CP, Arogundade $F$, Sanusi A, Adelusola K, Wokoma F, Akinsola A. Renal disease in HIV-seropositive patients in Nigeria: An assessment of prevalence, clinical features, and risk factors. Nephrol Dial Transplant. 2008, 23 (2): 741-6. https://doi.org/10.1093/ndt/gfm836

10. Cailhol, J., Nkurunziza, B., Izzedine, H, Nindagiye E, Munyana L, Baramperanye E, Nzorijana J, Sakubu D, Niyongabo T, Bouchaud O. Prevalence of chronic kidney disease among people living with HIVIAIDS in Burundi: a cross-sectional study. BMC Nephrol $\quad 12, \quad 40 \quad$ (2011). https://doi.org/10.1186/1471-2369-12-40

11. Awofala AA, Ogundele OE. HIV epidemiology in Nigeria. Saudi J Biol Sci. 2018;25(4):697703.

https://doi.org/10.1016/i.sjbs.2016.03.006

12. Okafor UH, Unuigbe El, Ojogwu LI, Oviasu E, Wokoma FS. Renal disease in HIV infected patients at University of Benin Teaching Hospital in Nigeria. Afr Health Sci 2011;(Suppl 1):

S28-S33.

https://doi.org/10.4314/ahs.v11i3.70067

13. Agaba El, Agaba PA, Sirisena ND, Anteyi EA, Idoko JA. Renal disease in the acquired immunodeficiency syndrome in north-central Nigeria. Nigerian Journal of medicine: journal of the National Association of Resident Doctors of Nigeria. 2003 Jul 1;12(3):120-5. https://doi.org/10.4314/imt.v4i2.35137 
14.Estrella MM, Parekh RS. Abraham A, Astor BC, Szczech,m LA, Anastos K, Dehovitz JA, Merenstein DJ, Pearce CL. Tien PC, Cohen $\mathrm{MH}$, Gange SJ. The impact of kidney function at HAART initiation on mortality in HIVinfected women. J Acquir Immune Defic Syndr 2010;55(2):217-220.

https://doi.org/10.1097/qai.0b013e3181e674f 4

15. Nigeria National Agency for the Control of AIDS. GARPR; Abuja, Nigeria: 2012. Global AIDS Response: Country Progress Report. Available:

https://www.unaids.org/en/dataanalysis/know yourresponse/countryprogressreports/2014C ountries Accessed 8 May 2021.

16. Erikpo UE, Kengne AP, Akpan EE, Effa EE, Bello AK, Ekott JU, George C, Salako BL, Okpechi IG.Prevalence and correlates of chronic kidney disease among ART- naïve HIV patients in the Niger Delta region of Nigeria. Medicine

(Baltimore) 2018;97(16):e0380. https://doi.org/10.1097/md.00000000000103 $\underline{80}$

17. World Health Organization. Interim WHO Clinical Staging of HIVIAIDS and HIVIAIDS case definitions for surveillance: African region, Switzerland: World Health Organization 2005. https://doi.org/10.32388/944sal

18. Wyatt CM, Schwartz GJ, Qwino Ong'or W,Abuya J, Abraham AG, Mboku C, M'mene LB, Koima WJ, Hotta M, Maier P, Klotman PE, Wools-Kaloustian K. Estimating kidney function in HIV-infected adults in Kenya: comparison to a direct measure of glomerular filtration rate by iohexol clearance. PloS one, 2013; 8(8): e69601. https://doi.org/10.1371/journal.pone.0069601

19. National Kidney Foundation. Summaries for patients. Diagnosis and evaluation of patients with chronic kidney disease. Recommendations from the National Kidney Foundation. Ann Intern Med 2003;129(2):136. https://doi.org/10.7326/0003-4819-139-2200307150-00006

20. Cockroft DW, Gault MH. Prediction of creatinine clearance from serum creatinine. Nephron 1976; 16(1):31-41. https://doi.org/10.1159/000180580

21.National Institutes of Health. Clinical guidelines for the identification, evaluation, and treatment of overweight and obesity in adults-the evidence report. Obes Res. 1998;6(2):51S-209S.
22. World Health Organization International Society of hypertension waiting Group 2003.World Health Organization/ (WHO)/ International Society of Hypertension (ISH) statement on management of hypertension. $\mathrm{J}$ Hypertens 2003; 21"1983-1992. https://doi.org/10.1097/00004872200311000-00002

23.Ali JH, Yirtaw TG. Time to viral load suppression and its associated factors in a cohort of patients taking antiretroviral treatment in East Shewa zone, Oromiya, Ethiopia, 2018. BMC Infect 2019; 19: 1084. https://doi.org/10.1186/s12879-019-4702-z

24. Umeizudike $\mathrm{T}$, Mabayoje $\mathrm{M}$, Okany $\mathrm{C}$, Abdulkareem F, Adeyomoye A, Okubadejo $\mathrm{N}$, Okpechi I. Prevalence of chronic kidney disease in HIV positive patients in Lagos, south-west Nigeria. Nephrology Reviews 2012; 4:22-26. https://doi.org/10.4081/nr.2012.e5

25. Agbaji OO, Onu A, Agaba PE, Muazu MA, Falang KD, Idoko JA. Predictors of impaired renal function among HIV infected patients commencing highly active antiretroviral therapy in Jos, Nigeria. Niger Med J 2011; 52:182-5. https://doi.org/10.4103/03001652.86133

26.Dada SA, Olanrewaju TO, Aderibigbe A, Chijioke A, Rafiu MO, Ajayi AO. Prevalence of chronic kidney disease in newly diagnosed patients with human immunodeficiency virus in Ilorin, Nigeria. Brazilian Journal of Nephrology. 2015 Jun;37(2):177-84.

27. Anyabolu EN, Chukwuonye II, Arodiwe E, Ijoma CK, Ulasi I. Prevalence and predictors of chronic kidney disease in newly diagnosed human immunodeficiency virus patients in Owerri, Nigeria. Indian J Nephrol. 2016; 26(1):10-15. https://doi.org/10.4103/09714065.156115

28. Mocroft A, Kirk O, Gatell J, Reiss P, Gargalianos P, Zilmer K, Beniowski M, Viard JP. Staszewski S, Lundgren JD. Chronic renal failure among HIV-1-infected patients. AIDS. 2007; 21(9):1119-1127. https://doi.org/10.1097/qad.0b013e3280f774 ee

29.Alfano G, Cappelli G, Fontana F, Lullo LD, Dilorio B, Bellasi A, Guaraidi G. Kidney disease in HIV infection. J Clin Med 2019;8(8):1254. https://doi.org/10.3390/jcm8081254

30. Hsieh M, Lu P, Kuo M. Lin W, Lin C, Lai C, Tsai J, Chen T, Hwang S, Chen Y. Prevalence of and associated factors with chronic kidney 
disease in human immunodeficiency virusinfected patients in Taiwan. J Microbiol Immunol 2015;48:256-262. https://doi.org/10.1016/i.jmii.2013.08.013

31.Wyatt CM, Winston JA, Malvestutto CD. Fishbein D, Barash I, Cohen AJ, Klotman ME, Klotman PE. Chronic kidney disease in HIV infection: an urban epidemic. AIDS 2007; 21(15):201-2103. https://doi.org/10.1097/qad.0b013e3282ef1b b4

32.Diana NE, Naicker S. Update on current management of chronic kidney disease in patients with HIV infection. International journal of nephrology and renovascular disease. 2016;9:223. https://doi.org/10.2147/iinrd.s93887

33. Huda NM, Alam KS, Ur-Rashid H. Prevalence of chronic kidney disease and its association with risk factors in disadvantageous populations. Int J Nephrol 2012, Article ID 267328. 7 pages. https://doi.org/10.1155/2012/267329

34.Adedeji TA, Adedeji NO, Adebisi SA, Idowu AA, Fawale MB, Jimoh KA. Prevalence and pattern of chronic kidney disease in antiretroviral naïve patients with HIVIAIDS. J Int Assoc Provid AIDS Care 2015; 14(5):434440.

https://doi.org/10.1177/2325957415587570
35.Abene EE, Gimba ZM, Agbaji OO, Agaba EI. Prevalence of chronic kidney disease among antiretroviral naïve human virus-infected patients. Sahel Med J 2018;21:42-6s. https://doi.org/10.4103/smi.smj 5316

36. Shoko C, Chikobvu D. A superiority of viral load over CD4 cell count when predicting mortality in HIV patients on therapy. BMC Infect 2019;19:169. doi.org/10.1186/s12879.019-3781-1

37. Mellors JW, Rinaldo CR, Gupta P, White RM, Todd JA, Kingsley LA. Prognosis in HIV-1 infection predicted by the quantity of virus in plasma. Science 1996;272(5265):1167-1170. https://doi.org/10.1126/science.272.5265.116 7

38. Marchewka Z, Szymczak A, Knysz B. Comorbidities as risk factors of chronic kidney disease in HIV-infected persons. Postepy Hig Med Dosw 2015; 69: 1364-1370. https://doi.org/10.5604/17322693.1186343

39. Mapesi H, Kalinjuma AV, Nigerecha A, Franzeck F, Hatz C, Tanner M, Mayr M, Furrer $H$, Battegay $M$, Letang $E$, Weisser $M$, Glass TR., KIULARCO Study Group. Prevention and evolution of renal impairment in people living with HIV in rural Tanzania. Open Forum Infect Dis https://doi.org/10.1093/ofid/ofy072 